\title{
The Influence of Non-linguistic Factors on the Rise and Fall of the Old Byelorussian Literary Language
}

\author{
BY
}

\author{
A. G. WARING
}

The history of the Russian language is usually synonymous with the history of Russian. Obvious as this may seem from the standpoint of modern Russian, it is less so when one is dealing with an earlier stage of Russian since Old Byelorussian constitutes a fascinating chapter in the development of East Slavonic, counterpointing remarkably the history of the language of Muscovy. As Je. F. Karskij, the first scholar credited with delineating the history of Byelorussian, puts it: 'Old Byelorussian is as worthy for the study of the history of Russian as is Old Russian.'1

The striking feature of the language which became Byelorussian is that it evolved an extensive and important written language, then lost it only to develop a later written language but on a different basis. Moreover, not just the written language but the language itself arose well within the recorded historical period - even within the literary period of the Slavs - and hardly less noteworthy is the part in this played by non- or extra-linguistic factors.

Indeed the rise and fall of the first Byelorussian written language could be seen as a classic, if not unique, example of the influence on a language of non-linguistic factors. This is the viewpoint taken in this article which seeks not so much to bring fresh evidence to light as to review, so to speak, its case history which was hardly less varied and variously represented than the fate of the area where it was used.

A look at the written language must begin with the language itself. It is now generally accepted that Sachmatov's view of the tribal origin of Byelorussian is a romantic projection onto the past of the present tripartite division of East Slavonic, and that there was a common Old Russian stage in which old tribal linguistic features had been disturbed by population shifts. ${ }^{2}$

The most general non-linguistic factor was the change in the socioeconomic pattern of life whereby tribal speech gave way to

1. Je. F. Karskij, 'Cto takoje drevneje zapadnorusskoje narečlfe', Trudy po belorusskomu i drugim slavjanskim jazykam, Moscow, 1962, p. 261. 2. F. P. Filin, Proischoždenije russkogo, ukrainskogo $i$ belorusskogo jazykov, Leningrad,
1972, pp. 45-6. 
territorially based dialects, as a result of which Old Russian came to be a continuous dialect spectrum marked by completion throughout of the characteristic East Slavonic changes consequent upon the resolution of the jers together with local features such as those later to harden into differences of language in the West, for example, early textual evidence of $ч>\mu$ in the Torgovyj dogovor Smolenska $s$ Rigoju $i$ Gotskim beregom (1229) and of $\mathrm{b}>\mathrm{i}$ in the Jevsevieve jevangelije (1283). ${ }^{3}$

The great specific non-linguistic factor was the rise of Lithuania in the 14th century and her expansion at her high point as far as the Black Sea and a few days' march of Moscow, the result of which was to cordon off politically the Western end of the Russian linguistic continuum and lay the foundations of West Russian in the same way as a later division of the Western lands between North and South gave rise to a further split into Byelorussian and Ukrainian.

P. Wexler denies the role of the separate fate of the Western lands as the origin of Byelorussian on the grounds that:

'... many of the features which became identified with Byelorussian can be traced back to the period preceding the formation of the Grand Duchy of Lithuania. The principal reason for the rise of Byelorussian was the realignments taking place in the Kiev-Paleśsie and Połack-Rjazan' dialect areas.' ${ }^{4}$

That the raw material of Byelorussian was ancient dialect is not in dispute: Karskij sets store in his defence of Old Byelorussian by the antiquity of its linguistic lineage. But F. P. Filin is surely right in stressing the limitations of purely linguistic factors in the formation of a language, or at least in the emergence of a distinction between closely related languages. He argues that there may be greater linguistic difference between the dialects of a given language - he cites the example of German - than between related independent languages: 'In order to determine whether closely related languages are independent not only linguistic, but historical and cultural data must be taken into account.' 5 He points out that the formation of the East Slavonic languages is newer than their dialect boundaries and cuts across ancient isoglosses and divisions.

By stating that the essential characteristic of a nationality is its own particular language, however close it may be to other related languages', Filin puts the emphasis firmly on non-linguistic factors. He goes on to summarize succinctly the relationship between linguistic and non-linguistic factors in the emergence of the East Slavonic languages:

'The events leading to the formation of separate East Slavonic peoples did not in themselves give rise to linguistic phenomena as such (except particular lexical layers) but gave direction to linguistic development and constituted the social basis for the working out of the laws inherent in each language. Finally, the differences between the East Slavonic languages became much

\footnotetext{
3. R. I. Avanesov (ed.), Smolenskije gramoty XII-XIV vekov, Moscow, 1963, p. 5; O. P. Bezpal'ko et al., Istorycna hramatyka ukrajins'koji movy, Kiev, 1957, p. 141 .

4. P. Wexler, A Historical Phonology of the Belorussian Language, Heidelberg, 1977, pp. 60-1.

5. Filin, op. cit., p. 637.
} 
more important than the differences between any dialects within each language.' ${ }^{6}$

As regards the subject of the present article, the written Old Byelorussian language, the importance of non-linguistic factors is by the very nature of a written language so much the greater, reflecting as it does the culture of its speakers in the widest sense. Moreover, to quote Filin again: 'The peculiarities of the development of the

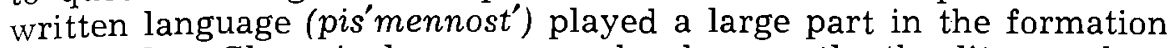
of the East Slavonic languages and subsequently the literary languages became a determining factor in their existence.' ${ }^{7}$ Indeed, as will be seen, in the opinion of many investigators the Old Byelorussian written language was almost entirely the product of nonlinguistic factors, if one makes two assumptions which are basic to this article: (1) 'non-linguistic factors' includes influence by another language - in the case of Byelorussian mainly Polish and Church Slavonic; (2) by the Old Byelorussian written language is meant the written language used in the area concerned, not just the written form of Old Byelorussian, any narrow view about the nature of which would beg most of the important questions here under discussion.

The Old Byelorussian period can be defined as lasting from the 14 th to the 18 th century. The 14 th century saw the appearance of the first gramoty with unmistakable Byelorussian phonetic features. From the end of the 15 th to the mid-17th century a variety of genres came into vogue while Byelorussian in the 18th century was largely confined to Polish school dramas.

It was a time of vast fluctuation in the fortunes of the West Russian lands from the rise of Lithuania, its merging with Poland until their final absorption by Muscovy less than two centuries since Poland had stood as the dominant power at the gates of Moscow.

The political vicissitudes were matched by a cultural, social and religious turmoil, the effect of which had far-reaching consequences for the nature and development of the written language.

The varying assessments of this language bear witness to the controversies surrounding its character and importance, and in themselves are some indication of the part played by non-linguistic factors, beginning with the name of the language itself. ${ }^{8}$ Contemporary sources, e.g. the 1588 Statute, Skaryna's prefaces, call it 'языкь руский' which adjective, originally designating the general East Slavonic territory, was restricted in the 15 th century virtually to the area of Byelorussia. The term had a territorial significance in official documents in the joint kingdom where Polish rulers called themselves 'Kings of the Russians'. For Skaryna the term denoted a language comprehensible to ordinary people as opposed to Church

6. ibid., p. 638 .

7. ibid.

8. The various names given to Byelorussian in this period are discussed by A. I. Zuraŭski in Historyja bietaruskaj litaraturnaj movy, I, Minsk, 1967, pp. 238-9. 
Slavonic - a religious consideration, not West Russian as opposed to the language of Muscovy - a political consideration. The appellations 'простый языкъ', 'простый діалекть', 'простая мова', have clear cultural or social overtones. In Muscovy where 'Russian' meant obviously the language of Moscow, the term 'бълороссийский язык' was used, again a territorial concept, whereas 'бълорусский' denoting the language inspired less confidence in tsarist Russia, to judge by A. I. Sobolevskij's comment about translations made from the 15 th to the 17th centuries in Moscow: '... with others we meit with the so-called Byelorussian language - of course, such translations are hard to distinguish from translations made in South West Russia'. ${ }^{9}$ Ciapinski's rendering of the Gospel in 1570 called the language 'зацный руский' while Zizanij's Catechism is 'по-литовски'.10

Scholars have introduced a variety of names, some of which betray non-linguistic preoccupations. Ukrainian scholars call the language 'українсько-білоруська мова'11 while Polish scholars have called it 'rosyjsko-polski język' or merely regarded it as a Polish dialect. ${ }^{12}$ The appropriate neutral term 'заходнеруская мова' is objected to on the grounds that it came into use when Byelorussian was being treated as a dialect of Russian in the 19 th century. ${ }^{13}$ As with the name of the language there are conflicting attitudes to its nature and status. Golovackij and Bodjanskij refused to name it at all because of its artificiality, the later declaring that 'no-one ever spoke it as it was the most revolting mixture it is possible to imagine that ever existed in Russia'. ${ }^{14}$ Golovackij claimed it was 'neither Byelorussian, nor Russian, nor Ukrainian, but an artificial bookish language, the like of which never has been spoken'. ${ }^{15}$

More recent scholars, too, have stressed the artificiality of the written language in terms of its mixed nature, its lack of creative culture and its remoteness from the spoken norm. A. Martel, for example, claims it was basically Church Slavonic with more Polish than Byelorussian elements. ${ }^{16}$

It is clear that the truth or otherwise of such sweeping statements depends upon the kind of written language in question and the date of the material. Golovackij's comments refer to the language of Skaryna; he takes a different view of the language of the gramoty, calling it 'pure Russian without the slightest influence of Polish which at that time was not used in writing'. ${ }^{17}$

Karskij divided the period of its use: '... in the 14th and 15th centuries the West Russian language was purer than in the 16th and 17 th centuries when it took in a mass of Polonisms and other alien excrescences'. ${ }^{18}$ The distortion of compressing the whole development

9. A. I. Sobolevskij, Zapadnoje vlijanije na literaturu Moskovskoj Rusi XV-XVII vekov, St. Petersburg, 1899, p. 13

10. See Karskij, op. cit., pp. 253-4.

11. For example, F. P. Medvedev in his Vstup do kursu istoryji ukrajins'koji movy, Kharkov, 1967, p. 78 .

12. Karskij, op. cit., p. 254.

13. Historyja bielaruskaj litaraturnaj movy, I, p. 239.

14. Quoted in Karskij, op. cit., p. 254.

15. $i$ bid.

16. A. Martel, La langue polonaise dans les pays ruthènes, Lille, 1938, pp. 38-44.

17. Quoted in Karskij, op. cit., p. 255

18. $i$ bid., p. 261 . 
of Old Byelorussian into a single papragraph can be seen first of all in the treatment of the most general non-linguistic factor affecting written East Slavonic, that is the use as the vehicle of religion and letters of a South Slavonic dialect. The interaction of Church Slavonic and the vernacular is, of course, the fundamental problem in any assessment of the written language. By and large West Russian continued the situation described for Old Russian thus by V. V. Vinogradov:

'... the Old Russian people possessed three types of written language, one of which - basically East Slavonic - served official correspondence, the second, properly speaking literary Church Slavonic, i.e. Russified Old Slavonic, served the needs of the faith and religious literature. The third kind, apparently combining widely elements mainly of living East Slavonic folkpoetic speech and Slavonicisms - was used in kinds of literary creation when artistic elements dominated.'19

However, the idea that West Russian not merely continued Church Slavonic but was a positive bastion of it, is a well-established opinion, as exemplified by V. I. Borkovskij and P. S. Kuznecov:

'The tradition of Church Slavonic as a literary language was maintained and cultivated in Byelorussia and the Ukraine almost more than it was in Muscovy ... Church Slavonic was used as the banner in the struggle for national, religious and cultural independence of the East Slavonic population of Poland... as a result... Church Slavonic held on longer as a literary language in the Byelorussian and Ukrainian territories than in the Russian.'20

After the Treaty of Lublin Church Slavonic did indeed become the symbol of the faith of the Orthodox and the object of special cultivation and veneration, and it was in Byelorussia that the first grammars of Church Slavonic were written by Smotrickij and Zizanij.

Ł. M. Sakun however declares that these grammars had greater effect in Moscow than in Byelorussia because of Polish dominance by that time. ${ }^{21} \mathrm{He}$ holds that the upsurge of Church Slavonic in the 16 th and 17 th centuries did not put down deep roots and ascribes the decline in the role of Church Slavonic to the following reasons: separation from Russia, influence of Polish and Catholicism, its unsuitability for officialese and the difficulty the population had in understanding it. ${ }^{22}$

Although taken separately the above two statements give conflicting impressions, they are really partial views of the same picture. The extent to which Church Slavonic was cultivated in Byelorussia compared with Muscovy does not alter the fact that the position of Church Slavonic was significantly different from its position in Muscovy where it was the language of the unchallenged established

19. V. V. Vinogradov, 'Voprosy obrazovanija russkogo nacional'nogo jazyka, Voprosy jazykoznanija, Moscow, 1956, 1, p. 10.

20. V. S. Borkovskij, P. S. Kuznecov, Istoričeskaja grammatika russkogo jazyka, Moscow, 1965 , p. 31.

21. E. M. Sakun, 'Značeńnie carkoŭnasłavianskaj movy ŭ raźvićci biełaruskaj litaraturnaj

22. ibid., pp. 11-12. 
Church and merged with Russian into a compromise literary language. S. I. Kotkov, analysing the chancellery language of Muscovy, claims that by the 17 th century the vernacular Church Slavonic bilingualism existed only at the extremes of church usage and simple speech, all the rest being a fusion of both strains. ${ }^{23}$

In Byelorussia the language of the established Church was Latin and Orthodoxy was the religion of the ruled, not the rulers. The weakness of the cultural and religious links with Moscow had undermined the position of Church Slavonic which in consequence was confined to the hard core of religious works, opening the way for the universal use of the vernacular in religious as well as secular writing. Furthermore, the written language in Byelorussia was affected only orthographically by the Second South Slav influence, ${ }^{24}$ which laid the foundation of the split between the language of Byelorussia and the Ukraine, where the Church Slavonic tradition gained momentum, eventually being used for ordinary secular purposes, notably by Peter Mohyla in the 17 th century. ${ }^{25}$

But in Byelorussia the decline in Church Slavonic made it unfamiliar to the faithful and hard even for the clergy to understand. ${ }^{\mathbf{2}}$

The 16th century was a time when Byelorussian was exposed to influences from the West which were barely felt in Muscovy. Foremost was the Reformation with its insistence on the use of the vernacular in Church services which greatly fostered and, as it were, legitimized the use of Byelorussian for religious purposes. Byelorussia became a crucible of religious conflict in which all the contenders, the Orthodox, Catholics, Uniates and Protestants had recourse to the vernacular in order to proselytize their beliefs. The need to go to the vernacular was also seen in its use by the Jesuits in the CounterReformation. Unlike the early fusion of Church Slavonic and the vernacular in Muscovy where familiarity with Church Slavonic made renderings into the vernacular unnecessary, Byelorussian emerged as a distinct written language in the second half of the 16 th century, as witness the translations made into it (especially by Ciapinski with parallel Church Slavonic and Byelorussian texts of the Jevangelije), while with Symon Budny's Catechism there appeared original religious writing in Byelorussian. ${ }^{27}$

At the same time Church Slavonic became stabilized, aided by an inflow of printed works from Muscovy, and constituted a separate stream. ${ }^{28}$

The major cultural event due to the spirit of the Reformation was Skaryna's translation of the Bible. Although on this account he was called the 'father of the Byelorussian literary language', it cannot be said that his language is any more than a Byelorussian recension of Church Slavonic. The considerable disagreement about the nature of

23. S. I. Kotkov, Moskovskaja delovaja $i$ bytovaja pis'mennost' XVII veka, Moscow, 1968,

24. Historyja bietaruskaj litaraturnaj movy, I, pp. 44, 80. 25. V. V. Vinogradov, ocerki po istorii russkogo literaturnogo jazyka XVII-XIX vv.,

26. Historyja bielaruskaj litaraturnaj movy, I, p. 115

28. tbid., p. 95 . 
his rendering (which also includes Czech and Polish words) stems from confusion about his purpose in making the translation, in particular from the prevalent idea that it was somehow his intention to produce a vernacular version, hence disappointment that his language seems artificial.

The controversies over Skaryna's language well illustrate the problem of separating linguistic from non-linguistic factors. A. I. Žuraŭski quotes Sobolevskij's opinion that Skaryna intended making available a Slavonic version of the Bible in an area where the scriptures in Slavonic were lacking, to which end he made such use of the vernacular as he saw fit to ensure it would be widely understood. ${ }^{29}$ As he says in his preface to his Psalms: 'I have put in the margin some words for ordinary people without destroying the Psalms themselves ... and some words in the Psalms which are incomprehensible to ordinary people will be found with their meaning in the margin in Russian.' ${ }^{30}$ This remark suggests that using the vernacular for its own sake was far from his mind, and that he attached great importance to Church Slavonic as the language of the holy writ and civilizing medium of the Slav peoples. The idea of Church Slavonic as the common heritage of the Slavs, an old belief given new life by the Reformation, is uppermost with the great figure of the second half of the 16th century, Symon Budny, who, commenting on the translation of the Bible, speaks of 'future translators of our Slavonic people, be they Poles, Russians, Croatians, Czechs . . . '31

If Skaryna is regarded not as the creator of the Byelorussian literary language, but as a figure of his time who used the language he saw as suitable for his elevated subject matter, having recourse to the vernacular because it was forced on him by the distance separating Church Slavonic from Byelorussian, a truer idea of the Byelorussian written language can be gained; in comparing his rendering of the Bible with the traditional Church Slavonic of the Ostrih Bible which came out some fifty years later in 1581, Žuraǔski concludes:

'Slkaryna's translation is a wide illustration of the popular language - partly the East Slav recension of Church Slavonic, partly a Byelorussian recension which did not last, while Byelorussian features are shown at every level.'32

The difficulity in understanding it Žuraŭski gives as stemming from linguistic factors, ${ }^{33}$ that is phonetic, morphological and lexical changes, and it is significant that the period during which the Old Byelorussian written language was operative was the time during which the basic changes took place which marked the separation of Old Russian into three languages. It is also worthy of consideration that Byelorussian remained more conservative morphologically than Russian and more conservative phonologically than Ukrainian where vowel fronting resembled Czech.

29. ibid., p. 119 .

30. ibid., p. 121

31. P. P. Achr

1968 , p. 79 .

32. Historyja bie 
Byelorussian thus was closest to Old Russian, which put it at a disadvantage compared with the more radical development of Ukrainian in resisting assimilation by tsarist Russia. With the new unity of Church Slavonic between Muscovy and the South West, the linguistic characteristics of Byelorussian were more easily passed off as provincial speech, and even scholars such as Sreznevskij recognized Russian and Ukrainian as languages, but regarded Byelorussian only as a dialect. ${ }^{\mathbf{3 4}}$

In the short run, however, the relatively conservative nature of Byelorussian enabled it to form the basis of a written language in that it had not departed too far from tradition - a powerful nonlinguistic factor which ignored, save unwittingly, formal changes in the vernacular, a conservatism reinforced by another non-linguistic factor making for continuity with the past, the advent of the printing press which, being largely in the hands of the clergy and hence influenced by Church Slavonic, disregarded such characteristic features of Byelorussian as dziekannie, the doubling of consonants in place of consonant plus jod, etc. But if it is comparatively easy to maintain formal tradition - or conversely, if changes in the form of a language are slow to become established in the written norm - the same is not true of vocabulary which shifts not only more rapidly but also largely unconsciously on the part of its speakers in response to need and fashion, drawing on availability as its source. It is in the development of the vocabulary of Old Byelorussian that non-linguistic factors played a decisive part.

Through isolation from Muscovy Byelorussian was thrown back on its own resources to widen its vocabulary. The weakness of the Church Slavonic influence meant that its use to coin words to meet new concepts as exemplified in the Byelorussian translation of certain philosophical treatises from Hebrew (of which the Logika is the best example) was only minor and ephemeral, whereas in Muscovy Church Slavonic became the main source of abstract and learned vocabulary. Because of the much closer links with the West availability entailed the adoption of foreign loan-words. Interesting evidence of this comes from alterations made in Muscovy to religious works of Byelorussian provenance where the words corrected are Byelorussian East Slavonic words instead of Church Slavonic and Polish or German borrowings not current in Russian. ${ }^{35}$

If in religious works Church Slavonic remained the model if not the custom the same was not the case with the main register and claim to fame of Old Byelorussian, the Chancellery language.

The adoption of Byelorussian as the official language, not only of the Russian lands annexed by Lithuania but in Lithuania itself, as distinct from the imposition of a foreign official language, was

\footnotetext{
34. See P. Ja. Jurhielevic, Kurs sučasnaj biełaruskaj movy $z$ histary cnymi kamientaryjami, Minsk, 1974, p. 26 .

35. Historyja bietaruskaj litaraturnaj movy, I, pp. 92-7.
} 
perhaps the most original circumstance in the history of Byelorussian and the outcome of a confluence of non-linguistic factors. The spread of Lithuanian power, a preferred alternative for the conquered population to Tatar rule, created a large nine-tenths Russian state at a time when the lands of the future Muscovy were in disarray under Tatar domination. All seemed set for the Lithuanians to emulate the Varangians with Vilna succeeding Kiev as a unifying centre.

Considerable intermarriage between Lithuanian and Russian princely families, including Olgerd and Vitovt (Witold), made Russian the adopted language of the ruling classes since Russian with its Kievan tradition of a literary language continuing into the 14 th century was culturally in advance of Lithuania which at that time had no written language.

The preponderance of Russian-speakers both in the country at large which had to be administered in a language the people could understand, and in the governing bodies such as the Sejm clearly helped give Russian preference over Latin, the cultural and official language of Poland, and over German, also current but politically undesirable as the language of a would-be engulfing power.

The Chancellery language too has suffered from the contraction of the sweeping statement. N. A . Kondrašov in his section on Ukrainian - in the Byelorussian section he makes only brief mention of Skaryna - writes thus:

'In the Ukrainian and Byelorussian lands which found themselves in the Grand Duchy of Lithuania Church Slavonic did not go into a decline, but became the language of state administration, the law, correspondence. This was the so-called Westrussian language with strong Byelorussian and Ukrainian features.' ${ }^{36}$

C. S. Stang, whose analysis of the Chancellery language is the standard work on the subject, takes the opposite view:

'... was wir in den öffentlichen Urkunden finden ist kein Kirchenslawisch sondern ein durch kirchenslawische Tradition beeinflußtes Westrussisch.' ${ }^{37}$

The Chancellery language however shows a deep duality. Although the closest of all forms of the Byelorussian written language to the vernacular, it is defined not in terms of a linguistic basis but a nonlinguistic one of scope and purpose with the original dialect basis eventually lost.

In documents emanating from the north - Polack, Viciebsk, Smolensk - there was cokan'e, confusion of e and $b$, ecme in the perfect tense, etc. These features were never found in documents from Vitovt's chancellery which was more like the Southern Ukrainian type. Among the documents from Kazimir the Ukrainian type is insignificant. In Alexander's reign the language is stable and later under Sigismund Augustus the Southern type disappears and the language most resembles the dialect around Vilna. The end of Kazi-

36. N. A. Kondrašov, Slavjanskije jazyki, Moscow, 1956, p. 107.

1935, p. 2 . 
mir's reign saw the emergence of a definite kind of Chancellery language which lasted through the reigns of Alexander and Sigismund i.e. from about 1480 until 1548. Thus there emerged a supradialectal written language for official purposes. Stang points to such consciously operating factors as the normifying activity of the head scribe. ${ }^{38}$ Hence the Chancellery language came to acquire a self-sufficiency and distance from the vernacular which must have been particularly evident in the Ukraine where it continued to serve, although increasingly at variance with both the vernacular and the heavily Church Slavonic literary language. G. Y. Shevelov gives the writien language in the Ukraine in the later period, 1480-1575, as Church Slavonic in religious writing and the secular language as basically Byelorussian. He too emphasizes the role of scribes in partly imitating their predecessors, partly innovating. 39

There are other manifestations of the influence of non-linguistic factors, some to be expected in such a register of language, others specific to the situation of Byelorussian of the time. A general characteristic is the need for official documents to carry authority, hence have a dignified accepted stable language widely recognized and showing continuity with the past, all of which makes for set formulae and phraseology, especially in respect of legal and business affairs where careful and recurrent fixed expressions are necessary to ensure precision and avoid ambiguity. Also official language is notoriously prone to become officialese, that is when such features become a whole style, sterile in its artificiality and unrepresentative of the living language. Byelorussian documents too were written 'according to a strictly devised format where regular set formulae are used, especially at the beginning and end. With specially important documents there was sometimes a whole philosophical discourse about the content and significance of writing in general'.10 It is interesting that these ceremonial expressions survived when the Byelorussian Chancellery language as such had given way: '... die Gerichtsprotokolle dieser Zeit häufig polnische Urkunden, mit russischen Einleitungs- und Abschlußformeln enthalten'. ${ }^{41}$ The huge collection of official documents known as the Metrika comprised a great variety of material including land registers, documents and letters from and to Sejms, official and private individuals. This was the other side of the linguistic picture - the need to do real and detailed business in this, the only language used for the purpose, hence its inevitably initimate connection with the life of the people, most immediately seen, perhars, in its use in legal proceedings where precision was required by law. ${ }^{42}$

This duality of the Chancellery language affects not just externals but its structure as well, giving rise to apparently diverse assessments of it, even by the same scholar. For example, Zuraŭski in one place

38. ibid., p. 62 .

39. G. Y. Shevelov, A Historical Phonology of the Ukrainian Language, Heidelberg, 1979, p 401.

40. Historyja bielaruskaj litaraturnaj movy, I, p. 38.

41. Stang. op. cit., p. 123

42. Historyja bietaruskaj litaraturnaj movy, I, p. 261. 
states that 'the Chancellery language (dziełavaja piśmiennaść) from the point of view of grammar and lexicon is very close to the then vernacular'.43 Elsewhere he writes: 'An analysis of the orthography, grammar and lexicon of the Chancellery language shows the considerable dependence of the orthography and grammar on traditional features, which do not correspond to the facts of living language. ${ }^{\mathbf{4 4}}$

This duality is complicated further by the shifts in the Chancellery language with progression in time, the second half of the 16th century being the pericd of its greatest spread with the addition of fresh material, notably the Statutes of 15066 and 1588 for the printing of which a secular type was used, which anticipates Peter the Great's graždanka. The Church Slavonic influence was virtually absent and despite the continuing traditional features, 'new orthographic, grammatical and lexical norms were being formed under the influence of the vernacular or through deliberate attempts to bring it closer to popular speech'. ${ }^{45}$ Of particular interest from the viewpoint of nonlinguistic factors was the convoluted syntax in which one can see the coming tcgether of tradition and functional complexity.

But as with the religious works, it is in the vocabulary that the influence of non-linguistic factors is most clearly visible, and again the same pattern emerges of development of Byelorussian internal resolirces and foreign loan-words, with the difference that Church Slavonic was not merely unfamiliar as in the religious language but inadequate to convey the degree of specialization in legal terminology, agriculture, trades and professions, etc.

The aspect of the development of the language which is due most directly to non-linguistic factors is the acquisition of loan-words, but Byelorussian scholars draw a distinction between those which came into the written language from the spoken, and those which were adopted into the written language often in preference to a native word. ${ }^{46}$

The former kind they see as a natural and healthy process in a vigorous language resulting from contacts with neighbouring countries such as brought German words early from trade with the Baltic and also from Hebrew and Polish. Polish, the main source of borrowings, also came in early through common economic and cultural links, and according to A. M. Bułyka 'the penetration by Polish words was relatively moderate during the first half of the 16th century as well'. ${ }^{47}$

But the striking feature of the subsequent fate of the Chancellery language and with it the whole of the written Byelorussian language is its eventual saturation with loan-words predominantly of Polish crigin or through Polish, the reasons for which are to be sought in the complex non-linguistic factors in play at the time.

The watershed in Byelorussian history is taken to be the Treaty

43. ibid., p. 55

4i. ibid., p. 59

45. ibid., p. 262.

46. For example, Zuraŭski (ibid., p. 230).

47. A. M. Bułyka, 'Pałanizmy ŭ starabiełaruskaj piśmiennaści rańniaha pieryjadu', Biełaruskaja mova $i$ movaznaŭstva, vyp. II, 1974, p. 21. 
of Lublin (1569) by which Poland and Lithuania became a single state, the Rzeczpospolita, the second largest country of Europe. But, in the words of a modern historian: "In reality the "union", which was regarded as an event of great political importance throughout the contemporary world, was less surprising than it seemed, and was in fact, the logical result of processes which had been developing during the preceding half-century. ${ }^{18}$ The reason why the Grand Duchy of Lithuania failed to become a 'genuine Russian state' by the 'absorption of the rulers by the ruled', was described by a recent historian as a 'dynastic accident' ${ }^{49}$ This accident was the marriage of Jagiclło in 1386 into the Polish ruling house, his conversion to Catholicism and the removal of his residence from Vilna to Cracow with all the shift in the direction of things, ideas and customs Poljsh this inevitably entailed. The word 'accident' is misleading, for the Alliance came about not by any personal whim but merely set the seal on a mutually advantageous union against the Germans and the Tatars.

It was Vitovt's defeat by the Tatars in 1399 and the success of joint action with Poland in breaking the power of the Teutonic knights at Tannenberg in 1410 that laid the foundation of the eventual joint Polish-Lithuanian State after the principle of a single ruler had been accerted in 1501. This merger came about reluctantly on the part of the Lithuanians because of the threat posed by the rising power of Muscovy. The defeat by Moscow of Tver', Lithuania's ally, and the gathering of the Russian lands under Ivan III in the 16th century had drastically simplified the political situation to one of confrontation between Muscovy and Poland, with the West Russian lands the disputed prize in between. But it was not only political expediency which drew Lithuania to Poland. Lithuanian power was internally hollow: ' $\ldots$ military necessity was the only basis of the RussoLithuanian state', writes W. E. D. Allen, ${ }^{50}$ and it was not surprising that when military necessity took the form of alliance with Poland, Polish manners, customs and ultimately language should fill the cultural gap, at least as far as the upper classes were concerner. Moreover, whereas the Lithuanian rulers blew hot and cold over political union with Poland according to their degree of success in resisting encroachment by Moscow, little reluctance was shown in adopting Polish ways. In the words of N. P. Vakar:

'By the end of the 16th century little indeed distinguished the Lithuanian Russian gentry from their Polish counterpart... Fighting against absorption by the State, they became the most effective agents of its Polonization.' ${ }^{51}$

The reason was the granting to the Lithuanian nobility of the same status in principle as the Polish nobility and while slow to be implemented because of cultural differences this step was decisive. As O. Halecki puts it:

48. W. E. D. Allen, The Ukraine. A History, Cambridge, 1940, p. 44.

49. J. D. Clarkson, A History of Russia from the Ninth Century, Lonclon, 1961, p. 65.

50. Allen. op. cit., p. 43

51. N. P. Vakar, Belorussia. The Making of a Nation, Harvard, 1956, p. 58. 
'... the long process of introducing Polish institutions was started immediately and, progressing through the whole Jagellonian period, became, independently of any changes in the political situation, the strongest force which attracted the Lithuanians into more and more intimate union with Poland. ${ }^{52}$

Renewed pressure by the Germans caused Poland to seek closer association with Lithuania. At Horodno in 1413 the political privileges as well of the Polish nobility were offered to the Russo-Lithuanian nobles who embraced Catholicism and in 1447 after the Germans tried to exploit differences between Catholics and Orthodox, the new Catholic King Kazimir put politics before religion and extended these privileges to the Orthodox nobility.

Horodlo also assimilated Lithuanian nobility into the Polish clan system; as Halecki says: 'The political importance of such an extracrdinary event could hardly be overestimated. ${ }^{53}$ The intractable differences over religion were allayed by the Union of Brest (1596) by which Catholics and Orthodox made common cause against Protestantism while the Orthodox sought to strengthen their position by the Union and the Catholics hoped to forestall claims by the now independent Patriarch in Moscow (1589) to Orthodox allegiance in Lithuania. Vakar writes:

'The Union of Brest broke the last barrier... The Brest Church Union was a logical sequence to the Union of Lublin. What the Poles were not able to attain politically, they achieved through Brest. Lithuania and Poland, politically independent though they were, began to merge into a cultural and spiritual whole. ${ }^{54}$

Thus the social basis was formed for the spread of Polish culture which blcssomed under Alexander who 'led Lithuania frankly in the direction of western culture.'55 In addition to founding Catholic churches, establishing the Magdeburg law and Polish law, Alexander introduced the Polish language to the Court of Vilna.

This beginning at the top the use of Polish set the tone for the nobility in what became a comprehensive linguistic reflection of the concomitant non-linguistic situation just described. In assessing the cause of the degradation of the Old Byelorussian written language, starting with the Chancellery language, several factors are evident. The Chancellery language was most of all linked with the social, economic and political life of Lithuania-Poland and so bore the brunt of the pressures making for change. The mere fact of being the official language exposed it to use by non-native Polish and Lithuanian speakers and the first signs of Polonisms were in documents emanating from Cracow. ${ }^{56}$ Consciously or unconsciously Polish speakers introduced their own speech habits into Byelorussian which is

52. O. Halecki, 'From the Union with Hungary to the Union with Lithuania. Jadwiga, 1374-99', The Cambridge History of Poland. From the Origins to Sobieski (to 1696), Cambridge, 1950 , p. 202

53. O. Halecki, 'Problems of the New Monarchy. Jagello and Witold, 1400-34', ibid., p. 217.

54. Vakar, op. cit., p. 56.

55. F. Papée, 'Imperial Expansion and the Supremacy of the Gentry, 1466-1506', The 56. Cambridge History of Poland. From the Origins to Sobieskt (to 1696), p. 267.

56. Bukyka, op. cit., p. 20. 
seen also in the religious language when the vernacular was used to inculcate Catholicism.

Polish kings and nobles often ignored Byelorussian in official life especially with such a major event as the replacement in the midcentury of Latin by Polish as the official language of Poland. It is hardly surprising that voices should be raised on the subject and at the Vilna Sejm (1565-6) a section of the nobility petitioned King Sigismund Augustus to have documents written in Latin or Polish. It was to answer this plea that the Statute contained the famous article that the scribe must use Russian and no other language. Thus the injunction which is always quoted as proof of the high standing of Byelorussian was in fact evidence of its decline. ${ }^{57}$

It is significant that the second half of the 16 th century, when Byelorussian emerged as an independent written language with Church Slavonic influence at its lowest ebb and the Chancellery language at full stretch, was also the period when it came under assault from Polish. It was as though the gap left by the absence of Church Slavonic was filled by Polish borrowings, a situation created by the strain put on the vernacular not only externally by the pressure of a rival language, but internaliy by the need to cope with new concepts and institutions. Vakar summarizes the situation thus:

'Modern legislation, such as... replacement of the ancient Russian system of veče by the Magdeburg Statute ... though enacted in the Russian language, bore a noticeable Polish stamp. The language itself ... had become adulterated with Polish words and idioms, since neither Church Slavonic nor the West Russian vernacular could keep pace with the lexical and semantic changes produced by the constant flow of foreign ideas into the country.' 58

Everything was happening too fast for the language to adjust. This is evident from translations made in the mid-16th century of the Psalms where a large number of different words are used to render the Church Slavonic original, and Žuraŭski remarks that this was a sign of weakness, not riches:

'... the instability of the vocabulary can be regarded as an inevitable stage... between the weakening of Church Slavonic and the increase in the specific weight of popular elements and borrowings from Polish. 59

The most obvious single addition to the Chancellery language was the influx of words of Latin origin towards the end of the 16 th century. The Chancellery Book of King Sigismund III of 1615-18 has a mass of Latinisms not found in the 1588 Statute. This shows three aspects of the situation. Firstly, the influence of the Polish official language, since they entered Byelorussian from Polish. Secondly, it illustrates again the ease with which words are adopted along with the new ideas they denote. Lastly, it raised the important question of the prestige attaching to this or that linguistic source which may or

57. Historyja bietaruskaj litaraturnaj movy, I, pp. 350-1.

58. Vakar, op, cit., p. 57.

59. Historyja bielaruskaj litaraturnaj movy, I, p. 185. 
may not relate to the need for a given loan-word. In fact as often as not it leads to unnecessary replacement of indigenous words. Martel draws attention to opposition to Byelorussian on the part of the Lithuanian nobility in favour of Latin which they considered specially related to Lithuanian just as they thought themselves descended from Romans. In 1576 the burgomaster of Vilna declared written Byelorussian to be 'alien, coarse and barbarous' but most of all that it lacked grammatical regulation. He favoured the use of Latin for official purposes and welcomed the newly constituted Jesuit schools where Latin was taught.60

Apart from the fanciful notions of the Lithuanians about their ancestry, there was no denying the general prestige of Latin, the venerated classical language, the official language of Western Christendom and lingua franca of Europe. This was particularly true in Poland. Halecki states that 'the Poles had been Latinized to an unexpected degree, and more than in any other European country their early cultural life had found its almost exclusive expression in the Latin language'. ${ }^{61}$ This situation remained until about the mid16 th century when the Polish language become predominant as part of what was Poland's 'golden age', coinciding with the Renaissance and happening at a time when the civilization served by Orthodoxy and Church Slavonic was in disrepair.

The result of the cultural and political impact on the RussoIithuanian nobility by the Poles was to split the population of the Western lands on social lines. J. D. Clarkson writes: 'Increasingly, religious and linguistic differentiation tended to be associated with class distinctions.' ${ }^{62}$ The nobility gravitated towards Poland which set the cultural pace, preferring Catholicism, Latin and Polish, whereas the mass of the populace clung to Orthodoxy and the old ways. But if the Statutes of 1529 and 1566 introduced throughout the lands of the Great Principality a social order similar in all respects to that existing in Poland, after the Brest Union there was considerable popular resistance to Polonization centred on the Fraternities with peasant uprising beginning in 1595 and gathering momentum with the success of Chmel'nic'kyj. The mid-17th century saw a diminution in Byelorussian writing and an increase in Church Slavonic with printed books appearing exclusively in Church Slavonic. Polish ceased to be the source of Byelorussian lexicon, a fact Zuraŭski attributes to a natural intention of self-preservation of a language so saturated with Polish words that any further increase was imposible, and also the religious and political antagonism to Polonization. ${ }^{63}$ The ban on Byelorussian as the Chancellery language in favour of Polish in 1697 Žuraŭski descrlbes as greatly exaggerated in its importance, since it merely registered a situation which had come about some time earlier. ${ }^{64}$ In any case it only affected the official language, yet all the other kinds of written Byelorussian went the same way.

\footnotetext{
60. Martel, op. cit., pp. 51-4.

61. O. Halecki, 'The Renaissance in Poland. Cultural Life and Literature', The Cambridge History of Poland. From the Origins to Sobieski (to 1696), p. 274.

62. Clarkson, op. cit., p. 66.

63. Historyja bielaruskaj litaraturnaj movy, I, p. 356

64. ibid., p. 354.
} 
It is easy to see a certain inevitability in the fall of the Old Byelorussian written language because of what seems to be its extraordinary and idiosyncratic situation. In order to put matters in truer perspective, however, it is only necessary to look at the development of Russian to realize that the Russian written language was subject to the same pressures and influences, moreover was if anything in an even greater state of chaos.

Until Peter the Great put an end to it and dealt, so to speak, directly with the countries of Western Europe, Poland was the middleman between the West and Russia. The same effect Polish culture had on the nobility in Lithuania spread to Muscovy at the height of Polish power in the second half of the 16 th century. 'By the end of the 17th centur" a knowledge of Polish was the hallmark of the educated nobleman', Vinogradov declares. ${ }^{65}$ Translations from Polish were exceeded in number only by those from Latin and many Polish words and expressions found their way into the written language and also the spoken language among the nobility. At the same time Latin came to be regarded on a par with Greek and Slavonic and began to affect the official language much as it did in Byelorussian, yielding, besides new words, changes in the structure of the sentence.

Latin also came in indirectly on the new wave of Church Slavonic from West Russia, especially the Ukraine, in the form of a Church Slavonic which, in Vinogradov's words, 'had become penetrated by the ideological elements of West European Catholic culture... while ecclesiastical-learned and secular literary styles from South West Russia began in the second half of the 17 th century to exercise a most powerful influence on the literary language of the Moscow State'. ${ }^{66}$ If their effect was not more lasting it was only because in the 18th century Russians were subjected to yet more cataclysmic forces of westernization when the written language went into the melting pot and, as with Byelorussian, neither Church Slavonic nor the vernacular was able to keep up with the new demands on it. By the end of the century Lomonosov's attempts to create a literary language from a synthesis of Church Slavonic and the Moscow Chancellery language had given way to unbridled foreign import and imitation with as the normifying influence not etymology but aristocratic taste formed in the image of Versailles and the Paris salon, leading to what Gribojedov's hero called 'that mixture of French and Nižnijnovgorod dialect'.

Despite the great similarity of the situation of the Russian and Old Byelorussian written languages, there were differences also which explain the survival of one and not the other.

There is a sense, of course, in which Russian did not survive if by the Russian written language were meant the purely East Slavonic strain. Without going as far as Unbegaun in regarding Russian as

65. Vinogradov, Očerki po istorii russkogo literaturnogo jazyka XVII-XIX vv., p. 32. 66. ibid., p. 19. 
Church Slavonic, it is clear that Russian has drawn heavily on Church Slavonic as a source of abstract vocabulary; with Byelorussian the weakening of Church Slavonic removed the source of indigenous culture, leaving the vernacular exposed to all influences from Poland. Vakar compares the role of Polish in Byelorussian with that of French in Russian. ${ }^{67}$ There is perhaps an important linguistic difference. For all the attraction first Latin then German, then finally and mostly, French had for Russian society of the post-Petrine period, these languages were obviously foreign in form as well as in origin, and would in the course of time constitute an indigestible blockage. The lasting benefit of French is probably far less the vocabulary itself which dated, but the semantic and phraseological possibilities it opened up in Russian as well as the simplification of the syntax.

But Polish was a close cognate language and as easy as Church Slavonic to assimilate. Halecki sees not the lainguage as the barrier to Polish cultural progress in Byelorussian so much as the difference in alphabet. ${ }^{68}$ This might seem less a non-linguistic factor than a nonlinguist's interpretation, but Žuraŭski as well points out that Byelorussian also influenced neighbouring languages, especially Polish because there was no great linguistic barrier:

'... Polish speech began to be penetrated by the peculiarities of Byelorussian enunciation and a whole quantity of Byelorussian words which thanks to the structural closeness of Polish and Byelorussian were readily assimilated in Polish and roused no resistance. ${ }^{69}$

Stieber too sees the difference in alphabets as confining Byelorussian influence on Polish in the 17th and 18th centuries to the spoken language..$^{70}$

The history of the formation of the Russian literary language in the 18th century provides ample illustration of the inherent difficulty in uprating commonly used words to give them the capacity for elevated thought and sentiment, and how much easier it is to resort to Church Slavonic or simply adopt the foreign word or expression by which the idea was brought. Above all it requires time for the language to adjust and settle into the new style. It was time that was lacking for Byelorussian which at the moment of emerging as an independent written form was plunged into the Polish cultural upheaval which itself after the year 1648, regarded as the date of the Polish cultural decline, was supplanted by the presence of Muscovy. The time factor was crucial in another way: 'In West Russia (Byelorussia and the Ukraine) the gentry and bourgeoisie began to experience the process of Europeanization earlier', Vinogradov points out. ${ }^{71}$ By the time Russia under Peter the Great came to bear the full weight of Europeanization the Russian state had become a major European power and Poland as a political force was spent.

T. P. Lomtev attributes the fall of the Old Byelorussian written

67. Vakar, op. cit., p. 58.

66. Halecki, 'The Renaissance in Poland...', p. 284.

69. Historyja bielaruskaj litaraturnaj movy, I, p. 231

70. Z. Stieber, A Historical Phonology of the Polish Language, Heidelberg, 1973, p. 145.

71. Vinogradov, ocerki po istorii russkogo literaturnogo jazyka XVII-XIX vv., p. 18. 
language to a lack of 'gosudarstvennost'72 - presumably loss of independence at a time when nationalism was coming to the fore. Certainly had Byelorussia achieved statehood like Muscovy it would have had a written language of its own, however artificial and corrupt. One could well imagine the mixture of Polish and Russian Engels describes ${ }^{73}$ used in Byelorussia in the same way as languages are used all over Europe composed of different strains - Scandinavian base with German loan-words, Anglo-Saxon base with Latin overlay - a language in fact like Russian in the 18th century. According to Auguste Brun 'a language is a dialect which has risen in society, the other dialects are its poor relations'. ${ }^{74}$ Written Byelorussian followed the opposite path, losing its official status with the absorption of the state by Muscovy, being relegated to the status of dialect of a still closer language with the common element of Church Slavonic as the link with Russian.

In conclusion, mention must be made of such a general nonlinguistic factor as illiteracy among the great bulk oi the population. This article has been concerned with the written language. The spoken langliage remained free from corruption, accepting only those loan-words which marked a change in the fabric of basic living, hence the significance of the distinction between borrowings which came into the written language from the spoken, and those coming from another language directly.

Somehow we accept that the fads and fashions in the written language of Russia were but surface movements on a linguistic sea as wide as the land and as deep as the peasantry. It was only by reaching down into the sources of the demotic that a true literary language could be created, beginning with Deržavin and brought to artistic perfection by Puškin's aristocratic democratization taking literature out of the confines of court or salon and making it and the language serving it the expression of the national spirit.

Yet with Byelorussian the connection between the written language and the spoken does not seem to be made.

Byelorussian in written form lasted only in comedies and satires in Jesuit schools as a source of amusement by the portrayal of simple folk. This may not be literature but it is comparable with the part played by the speech of the negative uneducated characters in Fonvizin's comedies which because of the nature of literature at the time was the only specific introduction of ordinary people and their language into Russian literature. The new written Byelorussian language which emerged as the result of poetry and publicistic literature in the 19 th century had no connection with or even memory of the Old Byelcrussian written language. This point, like the lowly survival of the vernacular in the comedies, is always stressed and perhaps overstressed. The difference between the new written Byelorussian language and its literature and the old is hardly greater than the difference between 19th-century Russian language and literature and

72. T. P. Lomtev, Belorusskij jazyk, Moscow, 1951, p. 3.

73. See Medvedev, op. cit., p. 100.

74. See P. Rickard, A History of the French Language, London, 1974, p. 52. 
th

the factitious imitative chaotic literary situation of the 18th century. The fact that Byelorussian was able to reassert itself in a literary form after such adverse non-linguistic factors as an official ban and all social pressure in favour of Russian - 'like Polish in an earlier age, it had become a mark of cultural and social distinction'75 - is surely proof of the inherent strength of the dormant demotic.

75. Vakar, op. cit., p. 74. 